\title{
Evaluation of chemical and antinutritional characteristics of obeche (Triplochition scleroxylon) and some mulberry (Morus alba) leaves
}

\author{
S. A. ADEDUNTAN ${ }^{1 *}$ and A. S. OYERINDE ${ }^{2}$ \\ ${ }^{I}$ Dept. of Forestry and Wood Technology Federal University of Technology P.M.B 704, Akure. \\ ${ }^{2}$ Dept. of Agricultural Engineering, Federal University of Technology P.M.B 704, Akure. \\ *Corresponding author, E-mail: niyi.gbenga@yahoo.co.uk
}

\begin{abstract}
The chemical composition and antinutritional contents of some selected varieties of white mulberry leaves and obeche leaves were investigated. Three varieties of mulberry leaves $\left(S_{36}, S_{54}\right.$ and $\left.K_{2}\right)$ were harvested from Ondo State sericulture centre while obeche leaves were harvested from Aponmu Forest Reserve located in Ondo State, Southwestern Nigeria, for analysis. Proximate composition, minerals and antinutritional contents were determined on dry matter basis for the samples. The percentage of crude protein in all the samples were significantly high $(\mathrm{P} \leq 0.05)$ with $34.31,21.66 \%, 21.55 \%$ and $21.24 \%$ in obeche, $\mathrm{S}_{36}, \mathrm{~S}_{54}$ and $\mathrm{K}_{2}$ respectively. Similarly, crude fibre follow the same trend with $20.73 \%, 13.70,10.81 \%, 13.70 \%$ and $8.74 \%$ respectively, while the percentage water content were $73.70 \% 79.35 \%, 72.16 \%$ and $76.00 \%$, in obeche, $\mathrm{S}_{36}, \mathrm{~S}_{54}$ and $\mathrm{K}_{2}$ respectively. The results further show that the samples contain zinc in the range of $34.4-57.5 \mathrm{mg} / \mathrm{kg}$, sodium 1069 - $1526 \mathrm{mg} / \mathrm{kg}$, manganese $14.83-24.37 \mathrm{mg} / \mathrm{kg}$, calcium $944-1467 \mathrm{mg} / \mathrm{kg}$, potassium 1684 $2170 \mathrm{mg} / \mathrm{kg}$, iron $129.70-238.00 \mathrm{mg} / \mathrm{kg}$, and magnesium $1450-2196 \mathrm{mg} / \mathrm{kg}$. Phytate is significantly higher $(\mathrm{P} \leq 0.05)$ in obeche than other treatments. Likewise, cyanide and tannin were significantly higher $(\mathrm{P} \leq 0.05)$ in $\mathrm{S}_{36}$ than other treatments (obeche, $\mathrm{K}_{2}$ and $\mathrm{S}_{34}$ ). However, these antinutrients (phytate, cyanide and tannin) were much lower than the permitted values in fruits and any other food items. The result of the chemical analysis showed that all the selected mulberry varieties and obeche leaves contained adequate level of food nutrients required for normal body functioning.
\end{abstract}

(C) 2009 International Formulae Group. All rights reserved.

Keywords: mulberry leaves, nutritional characteristics, obeche leaves, Proximate composition.

\section{INTRODUCTION}

The mulberry tree is a perennial woody plant which belongs to the family Moraceae, Genus Morus and species alba. It is a deeprooted perennial plant, capable of thriving under a variety of conditions ranging from temperate to tropical region. Several varieties of the tree are under cultivation in Ondo State, Nigeria, where the study was carried out. Mulberry tree is recognized as food plant for silkworm as well as an economic tree (Kasiviswanathan et al., 1988; Jaiyeola and Adeduntan, 2002). Its leaves have high protein content and is also used in cattle feed for milk production (Kasiviswanathan et al., 1988). The timber is used for furniture, tool handle and the fruits are used for making wine, while the seeds are used for making jam (Datta and Ravikumar, 1988). The mulberry can be grown as low bush, high trunk or deeprooted tree and as such, could be utilized in afforestation of land and anti-erosion programmes (Datta and Ravikumar, 1988). Powder of Morus alba leaves has been used to prepare a drink by some people as a healthy diet in Japan, but its chemical composition was not known (Shimizu et al., 1992). 
Trilochition (Triplochiton scleroxylon) (obeche) is indigenous to the humid tropical forests of Central and West Africa. It is a commercial and important timber species in its natural habitat, the timber is used as veneer and for light construction. The species have shown considerable promise as plantation species in tropical areas of Africa and Pacific (particularly in the Solomon Island). It has an excellent form, self-pruning and grows very fast. The main drawback with the species is its short-lived seed that has stimulated considerable research into vegetative propagation techniques. Juvenile leaf cuttings have been propagated successfully in conditions of high humidity in West Africa. Obeche has been used as hedges and for environmental stability. Its wood is used as fuel wood, while the sawn timber is used in building and for light construction, and the leaves are used as food.

Some plant species with edible fruits in lowland rainforest ecosystem of Southwestern Nigeria are noted to contain large quantities of protein and vitamins especially vitamins A, B, and C (Okafor 1979; Akachuku 1997). Their consumption therefore is able to augment the diet of people thereby preventing kwashiorkor and malnutrition especially in children. Some literature knowledge about the anti nutritional characteristics of these leaves should be stated. This study examined the nutrients and anti-nutrient potentials of obeche leaves and three varieties of mulberry leaves as a step towards establishing a wider and more purposeful utilization of these indigenous and exotic plant species, as well as to reduce the level of malnutrition in rural villages where these plants can be easily grown.

\section{MATERIALS AND METHODS}

Obeche leaves which were collected from different parts of the branches (i.e. top, middle and base) were obtained from Akure Forest Reserve, Aponmu, Nigeria, while the varieties of the mulberry leaves $\left(S_{36}, S_{54}\right.$ and $\mathrm{K}_{2}$ ) were collected from Ondo State Ministry of Agriculture Sericulture Centre, Akure, Nigeria. The mulberry varieties were given equal silvicultural treatments, while the analysis of the samples was carried out in triplicate using standard procedures (AOAC, 1990). Each of the leaf samples of obeche and the three mulberry varieties were oven dried at
$60{ }^{\circ} \mathrm{C}$, pulverized and sieved through a $2 \mathrm{~mm}$ mesh screen and further dried at $60{ }^{\circ} \mathrm{C}$ to constant weight, labeled and stored in an airtight plastic jar at $4{ }^{\circ} \mathrm{C}$ until required for analysis.

Proximate compositions of various samples were analyzed. Crude protein, crude fibre, crude fat and crude ash were determined by using the methods of Association of Official Analytical Chemist (AOAC, 1990). The samples were dissolved in 10\% HCL, filtered and diluted to $100 \mathrm{ml}$ before estimation of their heavy metal contents. The nitrogen free extract (carbohydrate) was estimated by subtracting the sum of weights of crude protein, crude fibre, crude fat and crude ash from the total dry matter. Phosphorus was determined by the Phosphovanado molybdate method of Ranjhan and Krisha (1980), while the other minerals were determined after wet digestion with a mixture of nitric, sulphuric and perchloric acids using an Atomic Absorption Spectrometer (AAS: Model SP 9). A corning flame photometer model 410 was used for the determination of $\mathrm{Na}$ and $\mathrm{K}$.

Extraction and precipitation and determination of phytate were done by the method of Wheeler and Ferrel (1971), as used by Aletor (1995), Enujuigha and Ayodele (2003). Iron in the precipitate was determined by the method of Makower (1970) Tannin values were obtained by adopting the method of Markar and Goodchild (1996), while hydrogen cyanide in the samples was determined by AOAC 1990 method.

Data obtained from proximate minerals and antinutritional properties were subjected to one-way analysis of variance (ANOVA) (Steel and Torrie, 1960). Mean separation was done by Duncan Multiple Range Test (DMRT) (Duncan, 1955). A P value of $<0.05$ was considered statistically significant.

\section{RESULTS}

Proximate composition of the leaf samples is presented in Table 1 . The result shows that there is wide variation in the samples and there were significant differences between the chemical analysis of obeche and mulberry leaves. The crude protein ranged from $21.24 \%$ to 21.66 in mulberry leaves while obeche leaves contain $34.31 \%$. The result further indicated that crude protein is significantly higher in obeche leaves than any 
leaf samples, while it is significantly lower in $\mathrm{K}_{2}$.

The level of carbohydrate in mulberry $\mathrm{K}_{2}, \mathrm{~S}_{54}, \mathrm{~S}_{36}$ varieties and obeche were $56.42 \%$, $49.04 \%, 47.27 \%$ and $30.04 \%$ respectively, with $\mathrm{K}_{2}$ having the highest values and obeche having the least value. However, carbohydrate in obeche leaf is significantly lower than any of the mulberry leaves. $\mathrm{S}_{36}$ has the highest fat level of $8.02 \%$ followed by $\mathrm{S}_{54}$ with $6.05 \%$ while obeche and $\mathrm{K}_{2}$ are $5.46 \%$ and $5.31 \%$ respectively. The value for $S_{36}$ is significantly higher than all the treatment, while there were no significant differences between percentage crude fat content for obeche and $\mathrm{k}_{2}$, which are significantly lower.

The ash content is the lowest in $\mathrm{K}_{2}$ (8. $19 \%)$ and the highest in $S_{36}(12.63 \%)$; obeche and $\mathrm{S}_{54}$ has $9.22 \%$ and $9.65 \%$ respectively. Percentage ash content is significantly higher in $\mathrm{S}_{25}$ but significantly lower in $\mathrm{K}_{2}$.

The fibre content is lowest in $\mathrm{K}_{2}$ $(8.74 \%)$ with obeche having the highest of $20.73 \%$. The lowest level of fibre in $K_{2}$ may be attributed to its high carbohydrate content of $56.42 \%$ while obeche that has the highest fibre resulted in the lowest carbohydrate $30.04 \%$. Generally, the result of the proximate analysis of the samples $\left(\mathrm{S}_{36}, \mathrm{~S}_{54}, \mathrm{~K}_{2}\right.$ and obeche) shows significant differences for crude protein, ash, crude fibre and carbohydrate but there was no significant difference in crude fat of obeche and $\mathrm{K}_{2}$.

Table 2 shows the level of antinutrients in various samples $\left(\mathrm{S}_{36}, \mathrm{~S}_{54}, \mathrm{~K}_{2}\right.$ and obeche), which hinder the utilizable nutrient in them. The mean values show that there was a significant difference in the phytate levels of the samples. The phytate content ranges from
$451.3 \mathrm{mg} / \mathrm{kg}$ in $\mathrm{K}_{3}, 456.8 \mathrm{mg} / \mathrm{kg}$ in $\mathrm{S}_{54}, 488.9$ $\mathrm{mg} / \mathrm{kg}$ in $\mathrm{S}_{36}$ to $997.8 \mathrm{mg} / \mathrm{kg}$ in obeche.

The cyanide content of the leaves is $1.01 \mathrm{mg} / \mathrm{kg}$ in $\mathrm{K}_{2}, 1.12 \mathrm{mg} / \mathrm{kg}$ in obeche, 1.24 $\mathrm{mg} / \mathrm{kg}$ in $\mathrm{S}_{54}$ and $2.14 \mathrm{mg} / \mathrm{kg}$ in $\mathrm{S}_{36}$ which is the highest value. The cyanide content for $S_{36}$ is significantly higher than for all other treatments, while other treatments were not significantly different from each other.

Table 2 also shows the tannin levels in the samples. $\mathrm{S}_{36}$ has the highest tannin content of $5.32 \mathrm{mg} / \mathrm{kg}$ which is significantly higher than for other treatments followed by $\mathrm{S}_{54}(3.78$ $\mathrm{mg} / \mathrm{kg})$, while $\mathrm{K}_{2}(3.65 \mathrm{mg} / \mathrm{kg})$ and obeche $(3.54 \mathrm{mg} / \mathrm{kg})$ were not significantly different from each other.

Table 3 shows the mineral contents of the leaves. There were significant differences in the zinc content between obeche and the other samples $\left(\mathrm{S}_{54}\right.$ and $\left.\mathrm{K}_{2}\right)$. Zinc content of S36 is significantly higher with $57.50 \mathrm{mg} / \mathrm{kg}$ than for other treatments, followed by obeche $48.60 \mathrm{mg} / \mathrm{kg}$ while $\mathrm{S} 54$ and $\mathrm{K}_{2}$ with value of $34.40 \mathrm{mg} / \mathrm{kg}$ is significantly lower compare with other treatment.

$\mathrm{S}_{36}$ has the highest magnesium content of $2196 \mathrm{mg} / \mathrm{kg}$ followed by obeche with 1700 $\mathrm{mg} / \mathrm{kg}$, both $\mathrm{K}_{2}$ and $\mathrm{S}_{54}$ have $1450 \mathrm{mg} / \mathrm{kg}$.

Calcium in obeche is significantly lower than any other samples with $944.7 \mathrm{mg} /$ $\mathrm{kg}$ while $\mathrm{K}_{2}$ and $\mathrm{S}_{54}$ ranked second with value of $1375 \mathrm{mg} / \mathrm{kg}$ and $S_{36}$ ranked the highest with $1467 \mathrm{mg} / \mathrm{kg}$ as shown in Table 3 .

Potassium level in $S_{36}$ is significantly higher than all other treatments with 2170 $\mathrm{mg} / \mathrm{kg}$ while the level in obeche, which was $1703 \mathrm{mg} / \mathrm{kg}$, is significantly higher than those of $\mathrm{K}_{2}$ and $\mathrm{S}_{54}$ with value of $1684 \mathrm{mg} / \mathrm{kg}$ each as shown in Table 3 .

Table 1: Proximate composition of mulberry leaves and obeche leaves.

\begin{tabular}{lcccccc}
\hline Samples & $\begin{array}{c}\text { Moisture } \\
\text { Content }(\%)\end{array}$ & $\begin{array}{c}\text { Crude } \\
\text { Protein }(\%)\end{array}$ & $\begin{array}{c}\text { Crude fat } \\
(\%)\end{array}$ & $\begin{array}{c}\text { Ash } \\
(\%)\end{array}$ & $\begin{array}{c}\text { crude fibre } \\
(\%)\end{array}$ & $\begin{array}{c}\text { Total } \\
\text { carbohydrate }\end{array}$ \\
\hline $\mathrm{S}_{36}$ & $79.35 \pm 0.69^{\mathrm{a}}$ & $21.66 \pm 0.0^{\mathrm{b}}$ & $8.02 \pm 0.30^{\mathrm{a}}$ & $12.63 \pm 0.20^{\mathrm{a}}$ & $10.8 \pm 0.80^{\mathrm{c}}$ & $47.27 \pm 0.41^{\mathrm{c}}$ \\
Obeche & $73.70 \pm 0.13^{\mathrm{c}}$ & $34.31 \pm 0.0^{\mathrm{a}}$ & $5.46 \pm 0.00^{\mathrm{c}}$ & $9.22 \pm 0.04^{\mathrm{c}}$ & $20.73 \pm 0.15^{\mathrm{a}}$ & $30.04 \pm 0.17^{\mathrm{d}}$ \\
$\mathrm{S}_{54}$ & $72.16 \pm 0.41^{\mathrm{d}}$ & $21.55 \pm 0.0^{\mathrm{c}}$ & $6.05 \pm 0.00^{\mathrm{b}}$ & $9.65 \pm 0.16^{\mathrm{b}}$ & $13.70 \pm 0.18^{\mathrm{b}}$ & $49.04 \pm 0.23^{\mathrm{b}}$ \\
$\mathrm{K}_{2}$ & $76.00 \pm 0.44^{\mathrm{b}}$ & $21.24 \pm 0.0^{\mathrm{d}}$ & $5.31 \pm 0.03^{\mathrm{c}}$ & $8.19 \pm 1.70^{\mathrm{d}}$ & $8.74 \pm 0.15^{\mathrm{d}}$ & $56.42 \pm 0.53^{\mathrm{a}}$ \\
\hline \multicolumn{5}{c}{ Values in the same column followed by the same superscript are not significantly different $(\mathrm{P}>0.05)}$.
\end{tabular}


Table 2: Anti-nutritional composition of the samples.

\begin{tabular}{lccc}
\hline Samples & Phytate $(\mathbf{m g} / \mathbf{k g})$ & Cyanide $(\mathbf{m g} / \mathbf{k g})$ & Tannin $(\mathbf{m g} / \mathbf{k g})$ \\
\hline $\mathrm{S}_{36}$ & $488.90 \pm 32.47^{\mathrm{b}}$ & $2.14 \pm 0.20^{\mathrm{a}}$ & $5.32 \pm 0.13^{\mathrm{a}}$ \\
Obeche & $997.80 \pm 130.27^{\mathrm{a}}$ & $1.12 \pm 0.20^{\mathrm{b}}$ & $3.54 \pm 0.04^{\mathrm{c}}$ \\
$\mathrm{K}_{2}$ & $451.30 \pm 0.00^{\mathrm{b}}$ & $1.01 \pm 0.00^{\mathrm{b}}$ & $3.65 \pm 0.01^{\mathrm{c}}$ \\
$\mathrm{S}_{54}$ & $456.80 \pm 9.45^{\mathrm{b}}$ & $1.24 \pm 0.20^{\mathrm{ab}}$ & $3.78 \pm 0.00^{\mathrm{b}}$ \\
\hline \multicolumn{4}{l}{ Values in the same column followed by the same superscript are not significantly different $(\mathrm{P}>0.05)}$.
\end{tabular}

The values of iron in $\mathrm{K}_{2}$ and $\mathrm{S}_{54}$ were $141.57 \mathrm{mg} / \mathrm{kg}$ and $141.75 \mathrm{mg} / \mathrm{kg}$ respectively. The value in obeche is significantly lower with value of $129.7 \mathrm{mg} / \mathrm{kg}$, while $\mathrm{S}_{36}$ is significantly higher than other treatments with value of $2380 \mathrm{mg} / \mathrm{kg}$. The mineral element in Table 3 however indicated further that cobalt, copper, cadmium and lead were not detected but their absence is not a nutritional disadvantage.

\section{DISCUSSION}

The result shows that crude protein ranged from $21.24 \%$ to 21.66 in mulberry leaves while obeche leaves contain $34.31 \%$ (Table 1). This shows higher protein content compared with some major vegetable leaves such as Solanum melongenas, Solanum nodiflorum and Vernonia amygdalina (FAO, 1990). Table 1 further revealed that obeche has the highest protein content followed by $\mathrm{S}_{36}, \mathrm{~S}_{54}$ and $\mathrm{K}_{2}$. The high protein values observed is in agreement with Kasiviswanathan et al. (1988) and it is an indication that both mulberry and obeche can be of food value in man, silkworm and animal. The limitation to the full utilization of obeche leaves could be due to high concentration of anti-nutritional factors mainly phytate and cyanide. This result equally indicated higher levels of crude protein compared to the commonly cultivated legumes such as cowpea; pigeon pea and lima beans as it was reported by Aletor and Adeogun (1995). Thus all species of mulberry and obeche leaves tested in this work could serve as substitute for existing plant protein and since the biomass yield of mulberry plant is very high at very short time (Adeduntan, 2003), coupled with lower cost of production, it could be highly recommended as food for man, animal and Silkworm. The level of carbohydrate in mulberry $\mathrm{K}_{2}, \mathrm{~S}_{54}, \mathrm{~S}_{36}$ varieties and obeche were $56.42 \%, 49.04 \%, 47.27 \%$ and $30.04 \%$ respectively with $\mathrm{K}_{2}$ having the highest values and obeche having the least value. There is a corresponding relationship between the carbohydrate content of the leaves and their protein values. As protein values increase in some variety, their corresponding carbohydrate value decreases. Thus, the higher the protein, the lower their corresponding carbohydrate, a situation that is very advantageous for rural sector of the economy that is facing food crisis today.

$\mathrm{S}_{36}$ has the highest fat level of $8.02 \%$ followed by $\mathrm{S}_{54}$ with $6.05 \%$ while obeche and $\mathrm{K}_{2}$ were having $5.46 \%$ and $5.31 \%$ respectively. These results signify that there are significant differences among the samples in fat levels and this agreed with the result obtained in the nutrient composition in mulberry leaves carried out in Asia (United Nations, 1993). The ash content was the lowest in $\mathrm{K}_{2}(8.19 \%)$ and the highest in $\mathrm{S}_{36}$ (12.63\%); obeche and $\mathrm{S}_{54}$ has $9.22 \%$ and $9.65 \%$ respectively. High ash content was considered to be a good source of mineral food (Enujiugha and Agbede 2000). The fibre content is lowest in $\mathrm{K}_{2}(8.74 \%)$ with obeche having the highest of $20.73 \%$. The lowest level of fibre in $\mathrm{K}_{2}$ may be attributed to its high carbohydrate content of $56.42 \%$ while obeche that has the highest fibre resulted in the lowest carbohydrate $30.04 \%$. Table 2 shows the level of anti-nutrients in various samples $\left(S_{36}, S_{54}, K_{2}\right.$ and obeche), which hinder the utilizable nutrient in them. The mean values show that there are significant differences in the phytate levels of the samples. The phytate content is significantly higher than any other treatment. Enujiugha and Agbede (2000) reported that phytin-p is known to be the primary storage form of 
S. A. ADEDUNTAN and A. S. OYERINDE / Int. J. Biol. Chem. Sci. 3(4): 681-687, 2009

Table 3: Mineral Elements of mulberry leaves and obeche.

\begin{tabular}{|c|c|c|c|c|c|c|c|c|c|c|c|}
\hline Samples & $\begin{array}{c}\text { Zinc } \\
\text { (mg/kg) }\end{array}$ & $\begin{array}{l}\text { Sodium } \\
\text { (mg/kg) }\end{array}$ & $\begin{array}{c}\text { Manganese } \\
(\mathrm{mg} / \mathrm{kg})\end{array}$ & $\begin{array}{l}\text { Calcium } \\
\text { (mg/kg) }\end{array}$ & $\begin{array}{l}\text { Potassium } \\
\text { (mg/kg) }\end{array}$ & $\begin{array}{c}\text { Iron } \\
\text { (mg/kg) }\end{array}$ & $\begin{array}{c}\text { Magnesium } \\
\text { (mg/kg) }\end{array}$ & Co & Cd & $\mathbf{P b}$ & $\mathrm{Cu}$ \\
\hline $\mathrm{S}_{36}$ & $57.50 \pm 0.45^{\mathrm{a}}$ & $1526 \pm 0.8^{\mathrm{a}}$ & $24.37 \pm 0.47^{\mathrm{a}}$ & $1467 \pm 1.05^{\mathrm{a}}$ & $2170 \pm 0.35^{\mathrm{a}}$ & $238 \pm 0.66^{\mathrm{d}}$ & $2196.4 \pm 1.23^{\mathrm{a}}$ & ND & ND & ND & ND \\
\hline Obeche & $48.60 \pm 0.46^{\mathrm{b}}$ & $1069 \pm 0.31^{\mathrm{c}}$ & $14.83 \pm 0.25^{\mathrm{c}}$ & $944 \pm 0.47^{c}$ & $1703 \pm 0.44^{\mathrm{b}}$ & $129.7 \pm 0.46^{\mathrm{c}}$ & $1700 \pm 0.55^{\mathrm{b}}$ & ND & ND & ND & ND \\
\hline $\mathrm{S}_{54}$ & $34.40 \pm 0.56^{\mathrm{c}}$ & $1081 \pm 0.32^{b}$ & $18.27 \pm 0.21^{\mathrm{b}}$ & $1375 \pm 0.7^{\mathrm{b}}$ & $1684 \pm 0.53$ & $141.7 \pm 0.45^{\mathrm{b}}$ & $1450 \pm 0.36^{\mathrm{c}}$ & ND & ND & ND & ND \\
\hline $\mathrm{K}_{2}$ & $34.40 \pm 0.46^{\mathrm{c}}$ & $1081 \pm 0.55^{\mathrm{b}}$ & $18.23 \pm 0.25^{\mathrm{b}}$ & $1375 \pm 0.43^{\mathrm{b}}$ & $1684 \pm 0.29$ & $141.5 \pm 0.49^{b}$ & $1450 \pm 0.35^{\mathrm{c}}$ & ND & ND & ND & ND \\
\hline
\end{tabular}


phosphorus in mature legume seed. The high phytin content in obeche has nutritional significance as it does not only make phytin-p unavailable to humans and monogastric but it also lowers the availability of many other essential divalent minerals such as calcium as reported by Aletor (1995).

The phytate contents of these leaves varying between $45.13 \mathrm{mg} / 100 \mathrm{~g}$ and 997.70 $\mathrm{mg} / 100 \mathrm{~g}$ which are less than what is obtained in some fruits such as guava $(327 \mathrm{mg} / 100 \mathrm{~g})$, Plantain $(553.08 \mathrm{mg} / 100 \mathrm{~g})$, and banana $(847.53 \mathrm{mg} / 100 \mathrm{~g})$ whereas the lethal standard value for phytate is $2500 \mathrm{mg} / 100 \mathrm{~g}$ (FAO 1990).

The cyanide content of the leaves is $1.01 \mathrm{mg} / \mathrm{kg}$ in $\mathrm{K}_{2}, 1.12 \mathrm{mg} / \mathrm{kg}$ in obeche, 1.24 $\mathrm{mg} / \mathrm{kg}$ in $\mathrm{S}_{54}$ and $2.14 \mathrm{mg} / \mathrm{kg}$ in $\mathrm{S}_{36}$ which is the highest value. This result is far below the standard permitted value for cyanide in fruits and in any other food value. The minimum standard cyanide value in leaves is $30 \mathrm{mg} / \mathrm{kg}$ (FAO 1990). These levels of cyanide may not have much effect on man and silkworm.

Table 2 also shows the tannin levels in the samples. $S_{36}$ has the highest tannin content of $5.32 \mathrm{mg} / \mathrm{kg}$ followed by $\mathrm{S}_{54}(3.78 \mathrm{mg} / \mathrm{kg})$, $\mathrm{K}_{2}(3.65 \mathrm{mg} / \mathrm{kg})$ and obeche $(3.54 \mathrm{mg} / \mathrm{kg})$. These values obtained were considered to be lower when compared with the standard value of $37 \mathrm{mg} / \mathrm{kg}$ (FAO, 1990). Thus these leaves are safe for consumption by man and livestock. Goldstein and Swain (1963) described Tannin as phenolic compounds with degree of hydrozylethyn with molecular size that is sufficient to form complexes with proteins thus making them unavailable. Rubino and Davidoff (1979) reported that cyanide of any part of plants often causes cyanide poisoning.

There were significant differences in the zinc content between obeche and the other samples $\left(\mathrm{S}_{54}\right.$ and $\left.\mathrm{K}_{2}\right)$ (Table 3 ). $\mathrm{S}_{36}$ has the highest zinc content with $57.50 \mathrm{mg} / \mathrm{kg}$ followed by obeche $48.60 \mathrm{mg} / \mathrm{kg}$ while both $\mathrm{S}_{54}$ and $\mathrm{K}_{2}$ has $34.40 \mathrm{mg} / \mathrm{kg}$. Zinc has been found to be an essential component of enzymes that plays critical role in protein and carbohydrate synthesis. The deficiency of zinc can cause break down in immune function of host defensive mechanism.

Calcium in obeche was significantly lower than any other samples with 944.7 $\mathrm{mg} / \mathrm{kg}$ while $\mathrm{K}_{2}$ and $\mathrm{S}_{54}$ ranked second with value of $1375 \mathrm{mg} / \mathrm{kg}$ and $S_{36}$ ranked the highest with $1467 \mathrm{mg} / \mathrm{kg}$ as shown in Table 3 . The values of calcium detected are in order of which is noted to be good for bone formation and osmo-regulation. Potassium level in $S_{36}$ is significantly higher than all other treatments with $2170 \mathrm{mg} / \mathrm{kg}$ while the level in obeche, which is $1703 \mathrm{mg} / \mathrm{kg}$, is significantly higher than those of $\mathrm{K}_{2}$ and $\mathrm{S}_{54}$ with value of $1684 \mathrm{mg} / \mathrm{kg}$ each as shown in table 3, which is good for nerves and muscle functions in man.

\section{Conclusion and recommendation}

Obeche (Triplochiton scleroxylon) contained very high protein and crude fibre that is very essential for man, livestock and silkworm's growth. Its leaves have been eaten by some communities in Ondo State, Nigeria, but its consumption has not been widespread. It is therefore suggested that the leaves be subjected to further treatments or processing to reduce the toxic level before processing for consumption. $\mathrm{K}_{2} \mathrm{~S}_{54}$ varieties of mulberry leaves should be encouraged by local farmers to feed their silk worms and livestock because they contain lower phytate, cyanide and tannin content, and are rich in essential minerals which are made available for utilization. This work thus supports the consumption of mulberry and obeche leaves by man since it has been reported by Datta (1992) that mulberry leaves serve as a source of delicious vegetable, which is very rich in protein.

\section{REFERENCES}

Adeduntan SA. 2003. Effect of fertilizer application on the growth and folia composition of mulberry leaf. Applied Tropical Agriculture Research, 11: 18-22.

Akachuku IO. 1997. Status of Forest Food Plant Species and Environmental Management in Southeast Nigeria. In Oduwaye EA, Obiaga PC, Abu JE (eds). Proceedings of $24^{\text {th }}$ Annual Conference of Forestry Association of Nigeria, Ibadan, Nigeria; 21-29.

Aletor VA. 1995. Compositional studies on edible tropical species of mushrooms. Food Chemistry, 54: 265-268.

Aletor VA, Adeogun OA. 1995. Nutrient and anti-nutrient composition of some tropical leafy vegetables. Food Chemistry, 53: $375-379$. 
AOAC. 1990. Official Method of Analysis. Association of Analytical Chemists $\left(15^{\text {th }}\right.$ edn). Washington D.C.

Datta RK, Ravikumar C. 1988. Sericulture and Rural Development International Congress on Tropical Sericulture practice. Lead paper 1, Central Silk Board, India; 4-5.

Datta RK. 1992. Guidelines for Bivoltine Rearing Central Silk Board. Ministry of Textile, Government of India, 39, Mahatma Gandhi Board, Banglare.

Duncan DB. 1955. Multiple range and multiple f-tests. Biometrics 11: 1 - 41.

Enujuigha UM, Agbede JO. 2000. Nutritional and Anti-nutritional Characteristics of African oil bean Pentadethra marophylle Benth seed. Applied Tropical Agriculture Research, 5: 1-4.

Enujuigha UM, Ayodele OM. 2003. Nutritional status of lesser-known oil seeds. International Journal of Food Sciencies and Tech., 38: 1-4.

FAO. 1990. World meat situation and outlook. Commodities and Trade Division, Food and Agriculture Organisation, Rome, Italy.

Goldstein JL, Swain T. 1963. Change of ripening fruits. Phytochem., 2: 271-283.

Jaiyeola V, Adeduntan SA. 2002. Sericulture in Ondo state: A means of alleviating rural poverty. In Forestry and Challenges of Sustainable Livelihood Proceedings of the $28^{\text {th }}$ Annual Conference of the Forestry Association of Nigeria held in Akure, Ondo state; 202 -207.

Kasiviswanathan K, Parankumar T, Chowdhary PC, Somashakara KS. 1988. Moricultural practical International congress on Tropical Sericulture practices, Lead paper 2. Central Silk Board, Bangalore, Indian; 11p.

Makower RV. 1970. Extraction and determination of phytic acid in beans (Phaseolus lunatus). Cereal Chemistry, 47: 28-292.

Markar AOS. Goodchild AV. 1996. Qualifications of Tannins. A Laboratory Manual. ICARDA, Akeppo: Syria IV; 25p.

Okafor JC. 1979. Edible Woody Plants in Rural Economy of Nigeria Forest Zone. In Okali DUU (Ed), Proceeding of a MAB state of Knowledge workshop on the Nigeria Rainforest Ecosystem, Nigeria, 262-301.

Ranjhan SR, Krishna G. 1980. Laboratory Manual for Nutrition Resesarch. Ranjhan SR, Krishna G (eds). Vicas Publ. Co.: New Delhi, India; 450p.

Rubino MJ, Davidoff F. 1979. Cyanide Poisoning from apricot seeds. J. A. M. A., 249: 241-256.

Shimizu P, Yazawa M, Takede N. 1992. Aromatic acid in leaves of Morus alba and their possible medical value. Sericologia, 32(4): $633-636$.

Steel RCD, Torrie JH. 1960. Principles and Procedures of Statistics ( $1^{\text {st }}$ edn). McGraw-Hill: New York.

United Nations. 1993. Techniques of Silkworms rearing in the tropics table 1. Nutritive compositions in mulberry leaf page 24. Campion, D. G. 1972. Some observations on the use of pheromone traps as a survey tool for Spodoptera littoralis. Cent. Overseas Pest Res. Rep., 4: 10 .

Wheeler VE, Ferrel RE. 1971. A method for phytic acid determination in wheat fractions. Cereal Chemistry, 48: 312-316. 